casemates, the Russian cruisers carried but few of their guns in casemates, most of the pieces depending upon gun shields for protection. The Japanese in this fight as in that off Port Arthur a few day before, elected to make the conflict a battle between gunners. They appear to have remained at long range (though the reports of the Japanese and Rus sian admirals do not agree on this point), and trusted to their superior pieces and better gunnery to disable the enemy at the cost of a minimum d a m a $\mathrm{a}$ to t a m a melves. This was obviously $t \mathrm{~h}$ e proper course for the Japanese. $\mathrm{S} \mathrm{u} \mathrm{c} \mathrm{h}$ fighting would have to be by the 8 -inch and 6 - inch guns, and of the 8-inch Russia possessed b u t twelve guns against sixteen carried by the Japanese; moreover four of those twelve were the short 30 caliber pieces of the "Rurik," whose velocity and range were very limited. Hence, in the earlier stages of the fight, the Japanese must have been able o reach the Russian ships with a bou t

twice the number of 8 -inch pieces that the Russians could hope to make effective upon the Japanese ships. In the 6-inch pieces, the Japanese had a tremendous superiority, carrying fifty-four against the sixteen mounted by the "Gromoboi." The "Rossia" and the "Rurik," it is true, mounted sixteen 5.5-inch guns apiece; but the one-half inch drop in caliber means a big drop in striking energy and carrying power, and it is doubtful if the 5.5-inch guns were able to do much effective work in this long-range fight.

It is a question as to which squadron had the advantage in the matter of speed. For although the Japanese ships were credited with from 21 to 22 knots trial speed, they were not sheathed, and for some months they have been tied closely to the task of watching the Straits to prevent a junction of the Port Arthur and Vladivostock squadrons; hence their bot. toms w e r e probably very foul, and their speed not much better $\mathrm{t} \mathrm{h}$ a $\mathrm{n}$ that of the "Rurik," or, ay, about 15 knots an hour. The immense advantage o $\mathrm{s} \mathrm{h}$ e a t h i $\mathrm{n}$ and coppering was shown at the close of the fight, whe the "Gromoboi" and "Rossia," which should $\mathrm{h} \mathrm{a} \mathrm{v}$ been captured or sunk by th victorious Jap anese, $w$ e $r$ able to draw a w a $y$ and make $\mathrm{g}$ o o d their escape to V l a d i v o. stock.

There is no new $l$ e s s o $\mathbf{n}$ taught by the fight. We simply see the accepted theories of construction and tactics once more strongly verifed. That the speed of the fleet is governed by the seed of the slowest ships was proved by the fact that the slower "Rurik" dropped behind and became the target for a terrific concentrated fire from the four Japanese cruisers; and although the two faster Russian ships repeatedly returned to her assistance, they were themselves so hard hit in doing this that they were forced to leave the "Rurik" to her fate. The su-

go far to enhance the value of the copper bottom in future warship construction.

\title{
THE NEW BALDWIN AIRSHIP.
}

BY J. MAYNE BALTIMORE

Capt. T. S. Baldwin, of Oakland, Cal., is the recent inventor and constructor of what proves to be a very successful dirigible airship.

The first and initial trial of the craft was made from I d o r Park, Oaklaned Since then several o ther trials $h$ a $v$ f $\mathrm{h} i \mathrm{c}$ proved $\mathrm{v}$ e $\mathrm{r} \mathrm{y}$ satisfactory.

No high altitude was at tained by the new airship. Capt. B a $1 \mathrm{~d}$. win's principal aim was to determine if the movements of his ship could be controlled. He as certained that this could be d o n e quite easily.

At a height feet, he circler several times clear around the large park, going bot h against a $\mathbf{n} d$ with the wind, and moving at various angles After being up nearly a $n$ hour, $\mathrm{C}$ a $\mathrm{pt}$.

B a l d w i n

perior armor carried by the newer Russian ships showed its value in protecting the water line from vital injury. The softer and less extensive water-line belt of the "Rurik" presented a weak point which the Japanese were quick to take advantage of. She was evidently so badly hulled that her ultimate sinking was only a question of time.

The two sheathed cruisers which escaped to Vladivostock present an interesting problem for the Japanese to solve. With their copper bottoms and with the large Vladivostock drydock available for cleaning, unless their engines have been seriously disabled, they can prey upon commerce without any fear of being captured for many months to come. For it is doubtful if there are any Japanese ships that can be put into condition to match them in speed. There can be condition to match them in speed. There can brought his ship back to the starting point, and safely reat crowds of spectators.

Subsequent trials have also been made, when it was demonstrated that in every revolution of the large propeller, and in every move of the steering gear, and of the weights which raise or lower the vessel at will, the plans of the inventor have been carried into effect. The large propeller, having two metallic blades, and nearly 6 feet in diameter, instead of being placed at the stern, is located at the bow of the frame or car, as in most recent airships of this type. In this manner the airship, instead of being pushed through the air, is pulled. This facilitates the steering as well as rais ing or lowering the ship.

The balloon, by means of which the whole machine is raised, is somewhat blunt cigar-shaped. It meas ures 54 fect in ength and 17 feet in $\mathrm{di}$ ameter in the middle. $\mathrm{T} \mathrm{h}$ e balloon is constructed of a very fine quality of silk, extremely strong and flexible, and with the $r$ e $t$ i c u . lated netting which attaches it to the car weighs only 90 pounds. $\mathrm{T} \mathrm{h}$ e balloon is inflated with hydrogen g a s, and at an or dinary disten sion pressure contains 8,000 cubic feet. To this balloon is attach ed the frame which s u p ports the propelling a $\mathrm{n}$ il steering mechanism. This
frame, which is made ot 
strong, light wood, is triangular in shape, the three ends uniting at a center at each extreme. This frame is 48 feet long, and is very securely braced and lashed. It has been thoroughly tested and wiil support 1,400 pounds with safety.

The engine which drives the propeller is one of the ordinary gasoline type, furnishes 7 horse-power, and weighs 60 pounds. The transmitting mechanism is so adjusted and geared as to cause the propeller to make 150 revolutions pet minute. Just what speed can be obtained under ordinary conditions, has not yet been definitely determined by the in-

The frame, or car is placed directly below the balloon-about 12 feet-and weighs 65 pounds. The total weight of the airship is 220 pounds, while its buoy ancy will lift nearly 500 pounds. The rudder, which is rectangular in shape, $5 \times 3 \frac{1}{2}$ feet, is very easily manipulated from any part of the car; and the engine is regulated by a steel lever. One person can very easily navigate this airship. The aeronaut can sit about midway of the frame, or he may move about freely if necessary without disturbing the general equilibrium to any extent.

A weight, which can be shifted from bow to stern, or vice-versa, permits the airship to be raised or lowered at wili. Capt. Baldwin intends soon to construct another frame that will be 6 feet longer and 15 pounds lighter. He thinks it will increase the speed and facilitate the steering.

So confident is the inventor and builder of success that he has already entered his airship in the $\$ 1,000,000$ prize com petition at the World's Fair. Capt. Bald win expects to start soon for St. Louis with his aerial machine.

In working the ship, the propeller may be reversed at pleasure, thus pushing the vessel backward, whenever the same is necessary or desirable. The trials showed that the ship very readily obeyed her helm.

\section{RECENTLY PATENTED INVENTIONS} Elect rical Devices.

TIIIRD-RAII, SYSTEM.-T. JEnkins, New York, N. Y. In this case the invention relates to the third-rail system for the ropelling of
("ars, its rincipal objects being to furnish an
effective rotecting-cover for the rail and a effective protecting-cover for the rail and a convenient support for the contact-shøe which
will permit the shoe to be moved inte and out ALECTRIC TR@LLEY. - G. @NDo, I)elancey, l'a. The invention has reference more espe-
cially to what are technically known as "trolle, - -inders," and one of the principal objects
thereof is to overcome numerous disadvantages and ob.jections common to many other strucThe means employed guide the device to assume the roper relation with the conducto separated entirely from the conductor whe
desired.

Machines and Mcchanical Devices. Fric "lion - Clutrcir.-C. Sexarour, Jefi-
ance, Ohio. The object of the invention is to ance, Ohio. The ol,ject of the invention is to
wrovide a new and improved cllitch arranged
to hold a movalle part under ordinary conditions in pesition, to allow a limited ylelding movement of the said part when under an ordinary strain, and to permit the parts to
move any desire distance when under an ex move any desired distance when under an ex
cessive stmin. It is a division of the applica
tion lor Letters latent of the Unite State tion rol letters l'atent of the United States
for a band-saw, formerly tiled by Mr. Sey-

Prime Movers and Their Accessories

WINIMILLL_T. J. MICLI:AN, Moose Jaw,

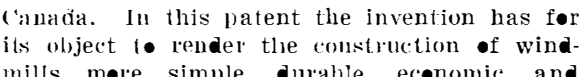
mills more simple, durable, economic, and iffective than ordinarily and to provide a
means whereby when the windmill is not in ne the wind-wheel will be housed and perfectly
l) be directed to the wheet as occasion may
require. Means are previded, acting always to keep the blades perfectly facing the wind, which blades are a

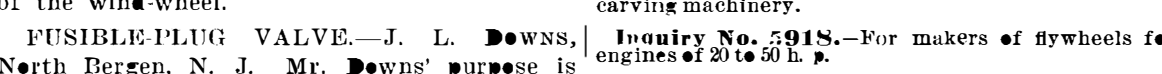

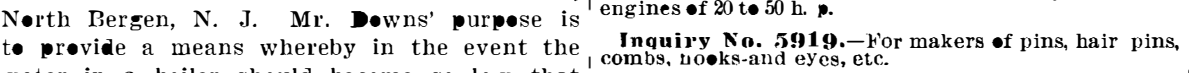
water in a boiler should become so low that ! Ingury No. 5920,-For makers of furnaces for
the lheat from the fire-box melts the fusible! smelting lead, tin and Babbitt dross.

Railways and Their Accessories.

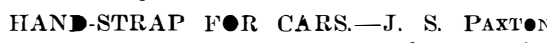
New Y॰rk, N. Y. The urpose of the inventio emeved at will, which advertisement may of the appear upon one or both sides
of another is to provide a frame eadily introduced or from which it may be

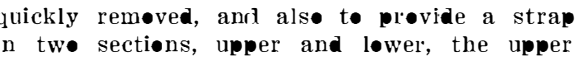
having a swivel connection with the frame wesigns.

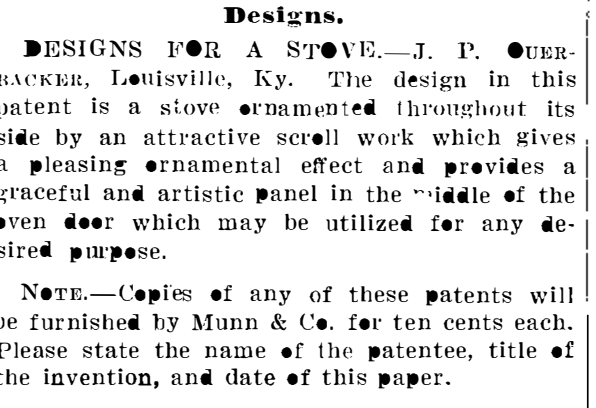

Business and Personal tuants.

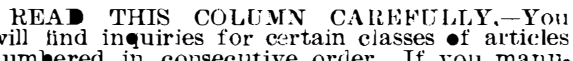

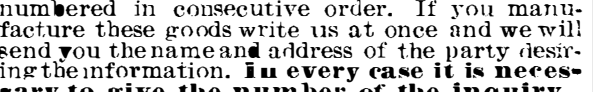
sary to give the number of the inquiry.
YI UN 8 co. Marme Iron Works. Chicaso. Catalogue free.
Jnquiro No. 5897.-For manufacturers of part - Duryea Power Co., Reading, P Inguirv No. 5898. - For the manufacturers and
he Brtitish agent for the ". Bliss" log. "L. S." Metal Polish. Indianadolis. Samples free.
Inquiry No. 5899.-For puzzles for advertising Perforated Metals, Harrington \& King Perforating Inquiry No. 59oo-- For makers of steam or hot
water heating apparatus for greenho uses. Handle \& Spøke Mchy. Ober Mfg. C•., 10 Bèll st,
Chagrin Falls, O. Inquiry No. 5901.-For machines for weaving
straw hats.
If it is a paper tube we can supply it. Textile Tube If it is a paper
Inquy, Fall River, Mass.
Inqu No. 590:2.-For a captive balloon to raise Inquiry
Sawming machinery and outfits manufactured by the
ane Mfg. Co.. Bex 13, Montpelier, vt. Inquiry No. 5903.-For manufacturers of spring
motors. American inventions negotiated in Europe. Wenze
$\&$ Hamburger, Equatable Building, Berlin, Germany. Inquiry No. 5904.-For makers of gas stoves and Patent No. 658.853, "Safety Device for Elevators" for
H. S., 265 Orange Street,
New Haven, Conn. Inquiry No. 5905.-For parties to turn, cut a ne
form of gasoline mantle burner in large quantities. In buying or selling patents money may be saved
nd time gained by writing Chas. A. Scott, 310 Cut ler Buildng, Rochester, New York.
Inquiry No. 5906.-For machines for planting
young onions. The celebrated "Hørnsby-Akroyd" Patent Safety oil
Engine is built by the De La Vergne Machine Com Dany
Foot of East 13sth Street, New Y ork. Foot of East 13sth Street, New Y ork.
Inquiry so. 5907. - For makers of tool handles
and small articles of walnut. Patented inventions of brass, bronze. comp'sition
laminum construction placed on market. Write to
American Brass Foundry Co.. Hyde Park, Mass. Inimiry No.5908.-F .. Hakers of lathes betwee
jeweler' and to.ot lathes. ve manufacture anything in metal. Patented
les, metal stamping, dies, screw mach. work, Metal Novelty Works, 43 Canal Street, Chicago.
Ioquiry No. 5909.-For makers of high-speed
steam engine castings to generate 12 to lti candle power. Manufacturers of patent articles, dies, metal stamp-
ing, screw machine work, hardware specialties, machin.
ery and toois. Quadriga Manufacturing Company,
South Cangl Inquiry No. 5910.-For makers •f laundry ma-
clunery. Inquiry No. 5g11.-For makers of gage rods,
ydrumeter jars, etc. Inguiry ko. 5912.-For makers of carpet-clean-
ng machinery. Inquiry No. 5913.-For machines for making old
carpets Interugs. In quiry $N$

Inguiry No. 5915.-For makers of power lace
nachines. Ingniry No. J916.-For makers of machine for
nakung copra, or for taking meat from the cocoanut. making copra, or for taking meat from the ceceanut.

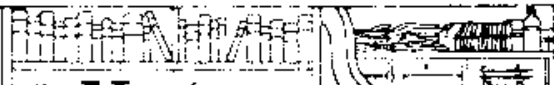 \\ Notes \\ and Querzes.}

\section{HINTS TO CORRESPONDENT}

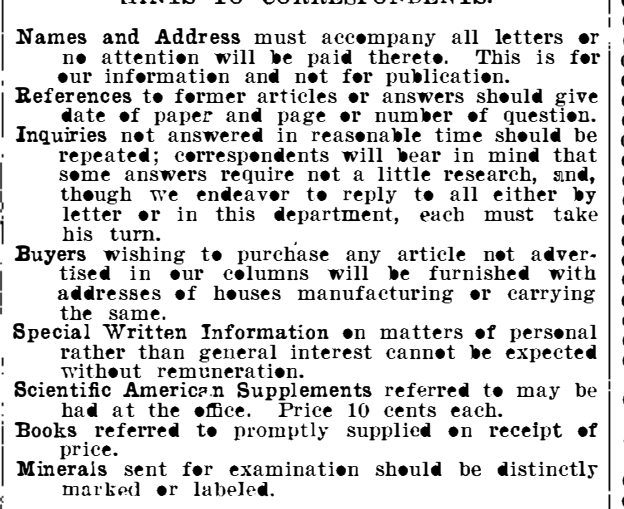

(9445) R. G. P. asks: Could two sets -f storage batteries be put inte a vehicle sø that one set will be running the vehicle and
the other will be charged by the same vehicle; and how fast has a dyname sot to run to
make electricity? A. If a storage battery is doing the work of running a vehicle it will not
have any power left with which to charge an have any power left with which to charge an
-ther battery strong enough to run the same - ther battery strong enough to run the same
vehicle. It would not be economical to use another storage battery. There is always a percentage of loss in transforming electricity from one form to another. A dyname may be -usand turns per minute.

(9446) LeG. L. W. asks: I am in want of information how to make small spark or induction coils, etc. Where may I find same?
A. You will find in our suppessice No. 160,
which we send for ten cents, full instructions with all needed illustrations and drawings for
making an induction coil which may give a making an induction coil which may give a
spark from 1 inch to $11 / 2$ inches in length. spark from 1 inch to $11 / 2$ inches in length.
SurrumEnT No. 1124, price ten cents, treat in a similar way a coil giving a spark 6 inche $\mathrm{y} \bullet$ will find details of coils giving spark

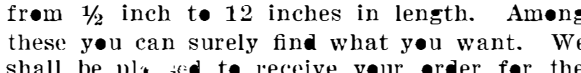
beok

INDEX OF INVENTIONS

For which Letters Patent of the United States were Issued for the Week Ending August 16, 1904

AND EACH BEARING THAT DATE Adding machine, W. - H. Pike, Jr.......... 767596
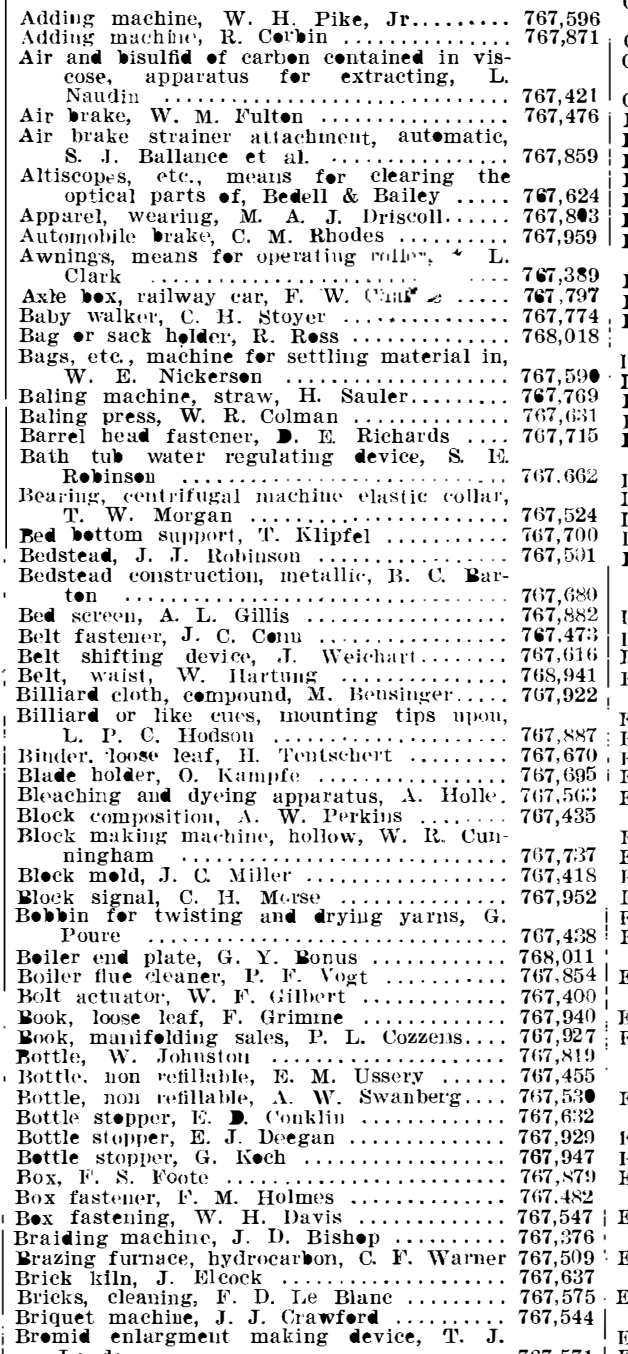

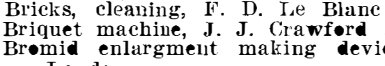

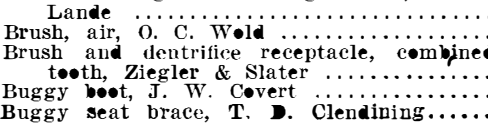

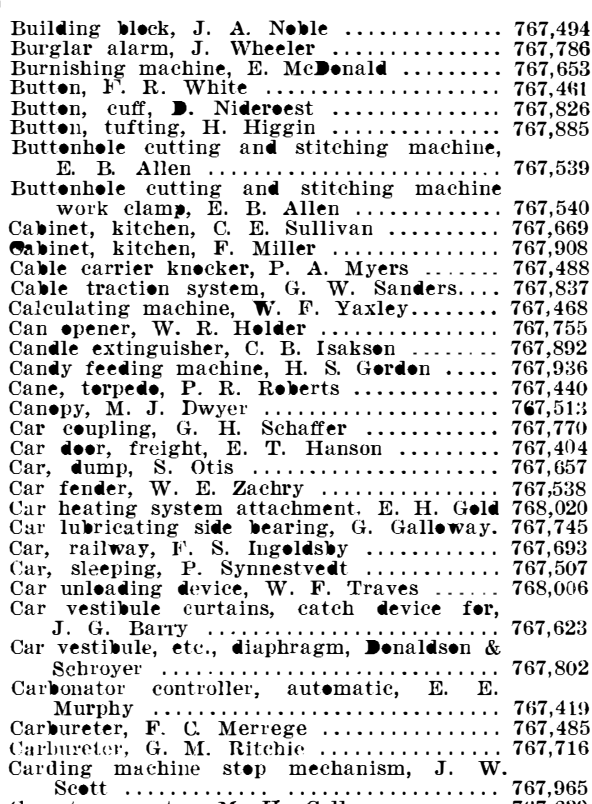

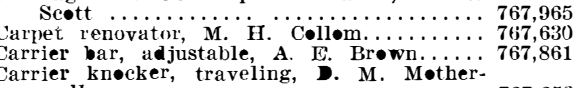

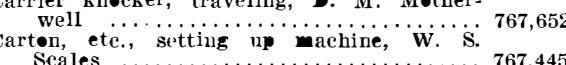

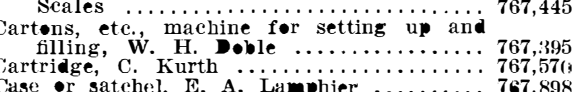

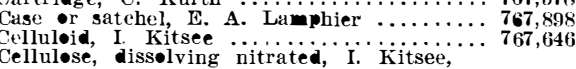

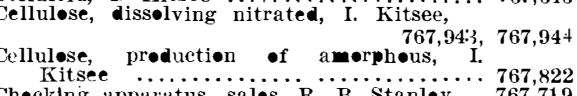

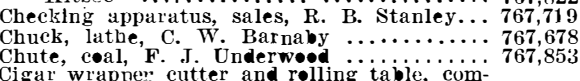

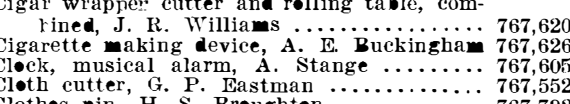

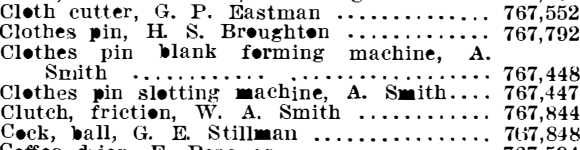

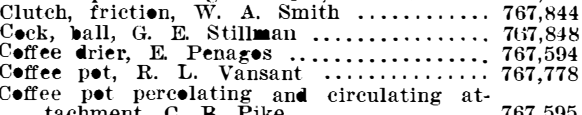

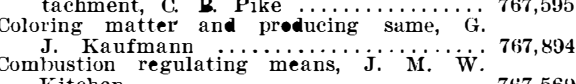

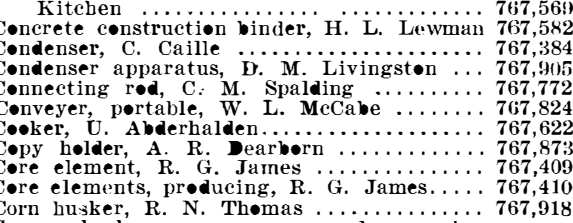

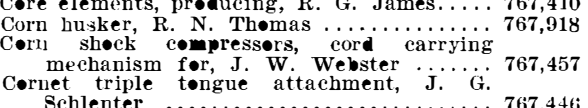

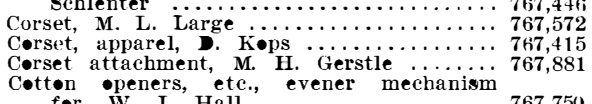

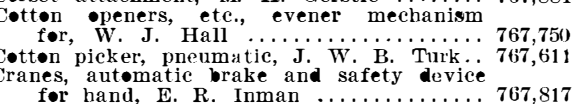

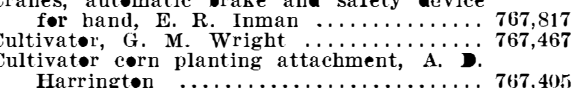

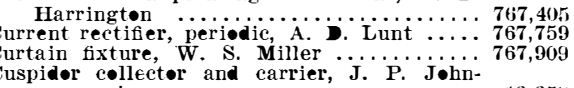

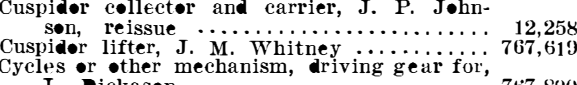

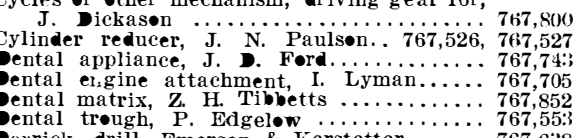

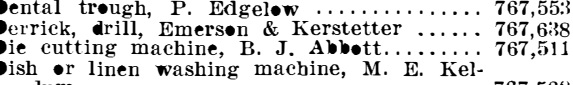

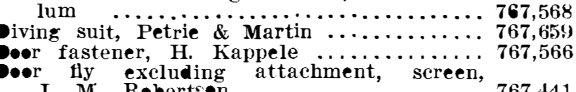

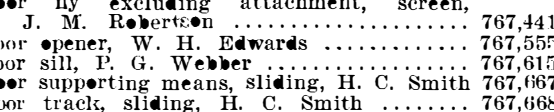

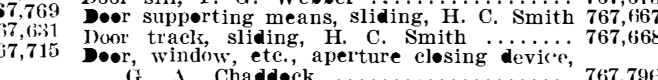

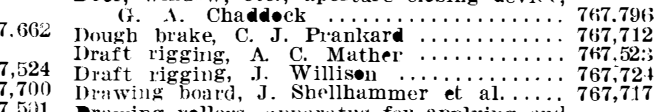

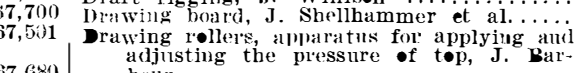

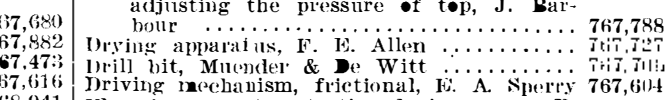

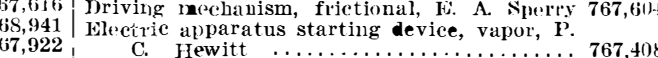

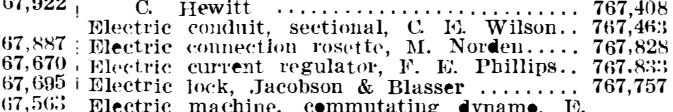

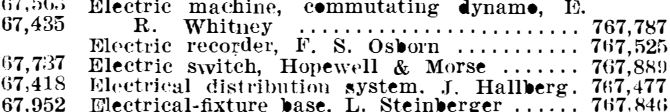

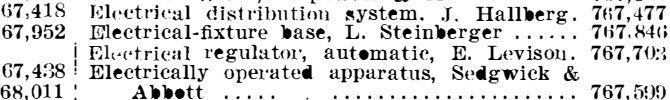

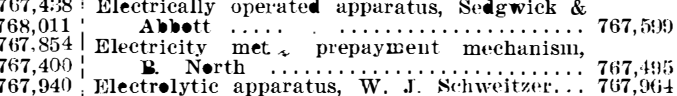

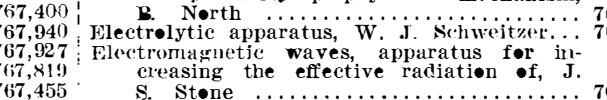

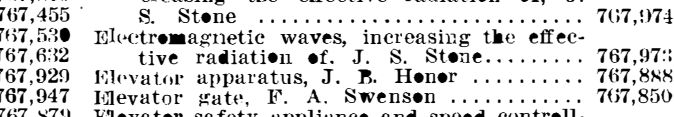

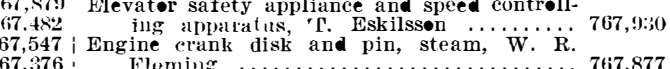

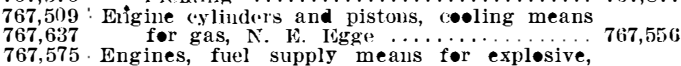

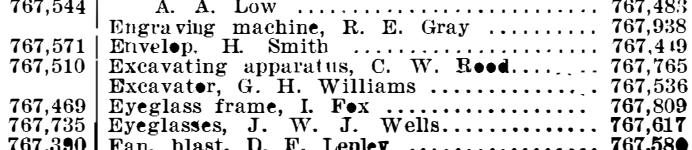

